\title{
Perception of the Discourse of Advertising Logos by Consumers of Mass Products: Case of Soft Drinks in Congo- Brazzaville
}

\author{
By Moyo Nzololo \\ Marien NGOUABI University
}

Abstract- Anchored in a perspective of relationship marketing, this article analyzes the perception of the discourse of advertising logos by consumers of soft drinks. Through a study carried out on 297 students, the article highlighted the fact that perception varies separately by level of education, gender, age, or a combination of both gender and level of education.

Keywords: relationship marketing, perception, logos, advertising, consumer, congo-brazzaville.

GJMBR-E Classification: JEL Code: FOO

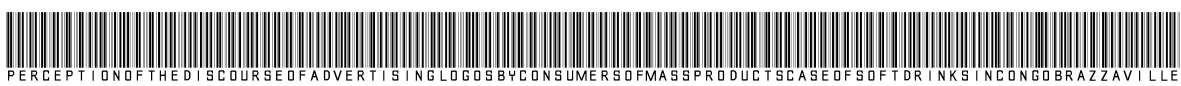

Strictly as per the compliance and regulations of:

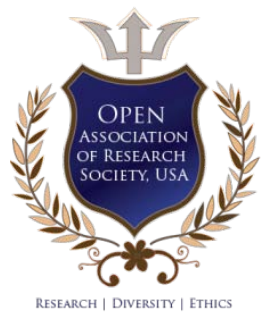

(C) 2020. Moyo Nzololo. This is a research/review paper, distributed under the terms of the Creative Commons AttributionNoncommercial 3.0 Unported License http://creativecommons.org/licenses/by-nc/3.0/), permitting all non-commercial use, distribution, and reproduction in any medium, provided the original work is properly cited. 


\title{
Perception of the Discourse of Advertising Logos by Consumers of Mass Products: Case of Soft Drinks in Congo-Brazzaville
}

\author{
Moyo Nzololo
}

Abstract-Anchored in a perspective of relationship marketing, this article analyzes the perception of the discourse of advertising logos by consumers of soft drinks. Through a study carried out on 297 students, the article highlighted the fact that perception varies separately by level of education, gender, age, or a combination of both gender and level of education.

Keywords: relationship marketing, perception, logos, advertising, consumer, congo-brazzaville.

\section{InTRODUCTION}

T his article is to be considered in the context of relational marketing or relationship marketing that stipulates: "A consumer is no longer a sole receiver, he also becomes an active transmitter of information related to organizations he is in relationship with (Gavard-Perret, 2000). The consumer becomes message actor, rather than being simply a receiver of such a message. We consider Berry's relational marketing, quoted by Flambard-Ruaud (1997): "Relational marketing consists of attracting, maintaining and reinforcing relationship with the client". As it is said by Bergadaà (2000), "What is at stake today is to define another logic or approach that considers the fact that the consumer has become a knowledge seeker and actor. In fact, this consumer makes inquiries, takes part to fora, suggests proposals to enterprises and researchers, goes beyond relationship borders".

The consumer figures out, compares, chooses, postpones the purchase, or simply gives up. That is the reason why we have carried out this research study with a population of students, on the ground that the latter represents the layer of the society that actively participates to liquid communication, characterized by a saying that "all communicate, and all is used in order to communicate". The consumer is subject to a lot of messages, not only from a multitude of medias, but also from consumers themselves. And this implies a communication that is current, omnipresent, multiform, changing, and sometimes imperceptible (TissierDesbordes, 2013). We have been cautious enough to lay a particular emphasis on gender, given that it has an influence on attitudes and behaviors of both male and female consumers (Gavard-Perret, op.cit).

Author: Faculty of Economic Science, Marien NGOUABI University, ESGAE- Congo Brazzaville. e-mail: emmalo2@yahoo.fr
In any communication between the receiver and the sender, there is the presence of noise, expressed by gap between the message sent and the message received. In this article, the message or the discourse is that of the advertising logo relating to soft drinks. Dorey and Zollinger (2000) underline that "As a general principle, in the design of advertising messages, wellestablished principles must be considered: the message ought to be swift, synthetic, clear and signed. However, abiding by these imperatives is not sufficient enough to ensure effectiveness in communication". Hence the existence of messages that are misunderstood, disconnected from the product, the brand and for which the consumer perceives no concrete or practical benefits, and therefore remains indifferent.

How could we make it possible for the consumer to better perceive the significance of the discourse proposed by the logo on the product?

From this core question, there are the six following secondary questions:

Q1.1: Does the contents of a logo representing a soft drink always meet expectations?

Q1.2: Are the logo's objectives perceived in an accurate manner?

Q2.1: Is there any link between the logo and the color of the beverage?

Q2.2: Can packaging play a role in the attractiveness of soft drinks?

Q3: Is there any link between the logo and the brand image of the company?

Q4: Is the message conveyed by the logo always explicit?

Through these questions, we want to study how consumers picture the discourse of advertising logos orientated towards soft drinks in Brazzaville, through the discourse of students on such an advertising logo to figure out the attractiveness of soft drinks from the logo, so as to better understand the place of communication in these enterprises. For that perspective, six hypotheses are pinpointed:

H1.1: The logo's contents meet the consumer's expectations according to the level of education.

H1.2: The logo's objectives are perceived in a clear and precise manner, according to the level of education. 
H2.1: There is a link between the logo and the color according the gender.

H2.2: The packaging triggers the consumption desire of the consumer.

H3: There is a link between the logo and the brand image of the company, according to the age of the consumer.

H4: The message conveyed by the logo is explicit according to the sex and the level of education.

We have conducted a survey of 297 students from the "Ecole Supérieure de Gestion et d' Administration des Entreprises - ESGAE" (a college of business administration) in Brazzaville, Congo, on real or prospective consumers of these soft drinks. The data have been processed on Sphinx software. After presenting the situation of art on logometry, then theoretical framework, we will tackle the part devoted to results and discussions, prior to concluding.

\section{il. Situation of art on Logometry}

Originated from the latinword "logos" or discourse and "metrics" or measure, logometry refers to a method of analysis and interpretation of a discourse, used in human and social science. The method is based on a computer-assisted analysis which combines both qualitative and quantitative interpretation of digital corpus of the discourse. It is a set of documentary and statistical processing of a text or discourses that emphasizes either the hyper textuality of digital corpus, or data analysis and textual statistics.

That is why logometry is to be seen as the natural extension of lexicometry (lexicon measurement) and textometry (text measurement). It is the analysis of the discourse or the logos in its linguistic and social dimensions, as stated by Mazière (2005) who considers that: "Logometry is, first of all, a computer-assisted "return" to discourse units in order to consolidate interpretation". As for Rouveyrol (2005), it is about an open and "integrative" method "whose core object is to give an account of relativity in discursive strategies" set by speakers. The interest of logometry for the marketer is to understand the importance of discourses, through symbolic representations of consumers products in a given cultural environment.

That is the reason why Philippe and Durand (2009) underline that authors from different or various research traditions concur and state that organizations which proactively seek to align their activities with their institutional environment through the evocation of symbols and appropriate actions, manage to improve their brand reputation. Studies conducted by Kapferer (2003) lay an emphasis on the brand as an important element for external communication. In the opinion of the author aforementioned, the brand is a source of confidence and notoriety of enterprises.
The company's brand is a sign of participation to proximity and implication marketing; it is the face value of the enterprise. The brand always bears the company's logotype or logo. It must stimulate, explore new needs, new wants and new products. It serves as a family name on which consumers' confidence is based.

As for Cova and Saucet (2014) who are studying street marketing operations, they insist on the fact that the latter are getting more and more important to managers, despite some regulatory constraints associated with such operations. These operations include: distribution of flyers and products, product animations, human animations, mobile tours, disguised actions, event-driven actions. In addition, the authors a fore mentioned point out that "The advantages of street marketing actions for a company lie essentially on direct relationship and emotional contact with a rather mobile target." This implies, as Filser (2015) states it, good understanding of factors that govern the purchasing behavior of consumers in a given environment. Such an understanding makes it possible to develop marketing action plans (communication and promotion) and identify the characteristics to be given to the product, based on the expectations of potential consumers.

The first models of consumer behavior have proved that the development of the consumer's affective begins with its cognitive states. These first two states lead to the conative state of the consumer's final behavior. In the opinion of the author above, it is possible that the consumer ignores the logo's attributes, while this logo influences his behavior. In the Bantu environment, Ibara (2013) states-in his work on logometry - that flashy colors, notably those from the rainbow, are most commonly used by enterprises in their logos, for they put the consumer more in resonance with vital energy.

However, if the consumer is repeatedly exposed to the products, under social pressure that value the product, he may be led to drive his preference based on a cognitive process, prior to deciding to buy the product. Mérigot and Nabec (2016) distinguish two nutritional logos which, according to their format, can warn consumers against any poor nutritional quality, prior to promoting good quality products. It is about descriptive nutritional logos and interpretative nutritional logos. The first are summaries of key nutritional values, while the second are synthetic nutritional indices of the nutritional quality of a product under the form of a single sign (a pictogram, a letter, or a color). Nevertheless, the two authors indicate that "the interpretative format, alone or combined with the descriptive format, is more efficient than the descriptive format".

\section{TheOretical FrameWOrK}

According to Granier and Guilbaut (1982), perception can be defined as a way for a consumer to 
understand, to grasp the meaning of the discourse, that is, the series of colors and codes of advertising logos. Perception is a matter of psychology, and it indicates how each consumer can be unable to internalize external stimulus. Understanding an advertising message largely depends on beliefs and habits of the targeted public.

For that matter, there are three levels of perception:

- Cognitive: relating to pieces of information, the competence that conveys prestige;

- Affective: relating to feelings or internalization;

- Conative: relating to feelings and actions.

According to Renaud and Sirieix (2012), it is possible to compare consumers 'perceptions in front of two different products with different logos. Based on their perceptions, the consumers prefer products that are not only respectful of the environment and health, but which also generate pleasure and taste associated with the consumption of such products. This could be analyzed for each of the customers through the analysis of the discourse perceived by each of them. To make its product known, the enterprise uses several means of advertising.

Advertising has an influence on us and sometimes goes as far as to impose us stereotypes that do not always tally with our nature and our own desires. Each individual acts spontaneously to the message: he compares it to his own knowledge and his environment, prior to accepting or rejecting it.
As for Granier and Guilbaut (op. cit.), advertising plays an important role in product knowledge, on the ground that it must be seen, read, believed, memorized, and must necessarily lead to acts of purchase. However, advertising has objectives and strategies. It is about drawing the consumer's attention, making the consumers understand the message conveyed, making the consumers believe in the importance of credit and making the consumers buy the product. As a strategy for publicity, it's all about being noticed, convincing and acting. On cans and bottles of soft drinks, there advertising logos mounted to the attention of customers. These logos bear a significance that pushes the consumer towards either rational motive or impulsive motive.

\section{Results and Discussion}

The beverage market in Congo is dominated by three products: beer, hygienic beverages and Spring or mineral water. The Congo Statistical Yearbook (2016, p.379) shows that Beer has moved from $157410^{3} \mathrm{hl}$ in 2010 to $361810^{3} \mathrm{hl}$ in 2014, while hygienic beverages moved from $69010^{3} \mathrm{hl}$ to $105310^{3} \mathrm{hl}$, whereas spring or mineral water moved from $20010^{3} \mathrm{hl}$ to $62810^{3} \mathrm{hl}$. Three companies dominate the market. The main company is BRASCO, created in 1994 and holding 65\% of the market share. It produces soft drinks (20\%) and beer $(80 \%)$ (Table $\left.\mathrm{n}^{\circ} 1\right)$. Its range of soft drinks includes 23 products.

Table n`1: BRASCO' sproducts

\begin{tabular}{|c|c|c|c|c|c|}
\hline Products & $\begin{array}{l}\text { Bottle } \\
\text { Volume }\end{array}$ & $\begin{array}{c}\text { Nature of } \\
\text { packing }\end{array}$ & $\begin{array}{c}\text { Quantity of bottles } \\
\text { in a pack }\end{array}$ & $\begin{array}{l}\text { Price per pack } \\
\text { (FCFA) }\end{array}$ & $\begin{array}{l}\text { Unit price per } \\
\text { bottle (FCFA) }\end{array}$ \\
\hline $\begin{array}{ll}\text { - } & \text { Coca cola } \\
\text { - } & \text { Fanta orange } \\
\text { - } & \text { Fanta passion } \\
\text { - } & \text { Pulp orange } \\
\text { - } & \text { Sprite } \\
\text { - } & \text { Coca zéro }\end{array}$ & $30 \mathrm{cl}$ & Plastic & 12 & 3000 & 300 \\
\hline $\begin{array}{ll}\text { - } & \text { Coca cola } \\
\text { - } & \text { Fanta orange } \\
\text { - } & \text { Panta passion } \\
\text { - } & \text { Coca zéro } \\
\end{array}$ & $50 \mathrm{cl}$ & Plastic & 12 & 4750 & 500 \\
\hline $\begin{array}{ll}\text { - } & \text { Coca cola } \\
\text { - } & \text { Fanta orange } \\
\text { - } & \text { Panta passion orange } \\
\text { - } & \text { Sprite } \\
\text { - } & \text { Coca zéro } \\
\end{array}$ & $30 \mathrm{cl}$ & $\begin{array}{l}\text { Glass } \\
\text { bottle }\end{array}$ & 24 & 5000 & 250 \\
\hline $\begin{array}{ll}\text { - } & \text { Coca cola } \\
\text { - } & \text { Fanta orange } \\
\text { - } & \text { Fanta passion } \\
\text { - } & \text { Sprite } \\
\text { - } & \text { Coca zéro } \\
\end{array}$ & $50 \mathrm{cl}$ & $\begin{array}{l}\text { Glass } \\
\text { bottle }\end{array}$ & 12 & 4800 & 500 \\
\hline
\end{tabular}

Source : BRASCO, Sales Management Dept., 2020 
In this table, we notice that there is no $50 \mathrm{cl}$ Sprite in plastic bottle on the one hand, and that, on the other hand, products "package are made up of both plastic and glass bottles. However, it should be noted that there is a serious problem related to shortage or lack of glass bottle.
RAGEC is the second company, created in 2004 and with a market share of 25\% (Table 2). Its products are essentially mineral water (75\%) and soft drinks (25\%). We notice a great variety of bottle volumes and therefore prices. RAGEC's range of soft drinks includes 14 products.

Tableau nْ2: RAGEC products

\begin{tabular}{|c|c|c|c|c|c|c|}
\hline & Products & $\begin{array}{l}\text { Bottle } \\
\text { Volume }\end{array}$ & $\begin{array}{c}\text { Nature of } \\
\text { packing }\end{array}$ & $\begin{array}{c}\text { Quantity of } \\
\text { bottles in a pack }\end{array}$ & $\begin{array}{c}\text { Price per pack } \\
\text { (FCFA }\end{array}$ & $\begin{array}{c}\text { Unit price per bottle } \\
\text { (FCFA) }\end{array}$ \\
\hline & $\begin{array}{l}\text { American cola } \\
\text { Planète orange } \\
\text { Planèteananas } \\
\text { Fanta passion } \\
\text { Sprite Bubelup }\end{array}$ & $35 \mathrm{cl}$ & Plastic & 12 & 2250 & 250 \\
\hline - & Orangina & $33 \mathrm{cl}$ & Plastic & 6 & 1550 & 350 \\
\hline - & Orangina & $50 \mathrm{cl}$ & Plastic & 6 & 2330 & 500 \\
\hline : & $\begin{array}{l}\text { Tampico orange } \\
\text { Tampico mangue } \\
\text { Tampicopomme }\end{array}$ & $35 \mathrm{cl}$ & Plastic & 12 & 2150 & 250 \\
\hline - & Reaktor & $33 \mathrm{cl}$ & Plastic & 6 & 2330 & 500 \\
\hline - & Jus Vita & $12.5 \mathrm{cl}$ & Plastic & 21 & 1990 & 150 \\
\hline - & Jus Perla & $1 \mathrm{~L}$ & Plastic & 12 & 8500 & 1000 \\
\hline - & Jus Perla & $20 \mathrm{cl}$ & Plastic & 24 & 4500 & 250 \\
\hline
\end{tabular}

Source: RAGEC, Sales Management Dept., 2020

The third company is BRALICO, created in 2013, and holds $10 \%$ of the market share. It produces varieties of beer (85\%) and soft drinks (15\%) (Table 3). We notice that BRASCO's range of soft drinks includes only 3 products, and that they are undifferentiated in terms of price. We are in a situation where the price does not reflect the quality.

Table $n^{\circ} 3:$ BRALICO

\begin{tabular}{|c|c|c|c|c|c|}
\hline Products & $\begin{array}{c}\text { Bottle } \\
\text { Volume }\end{array}$ & $\begin{array}{c}\text { Nature of } \\
\text { packing }\end{array}$ & $\begin{array}{c}\text { Quantity of bottles in a } \\
\text { pack }\end{array}$ & $\begin{array}{c}\text { Price per pack } \\
\text { (FCFA) }\end{array}$ & $\begin{array}{c}\text { Unit price per bottle } \\
\text { (FCFA) }\end{array}$ \\
\hline Coca world & $50 \mathrm{cl}$ & Glass bottle & 20 & 4700 & 300 \\
\hline Top passion & $50 \mathrm{cl}$ & Glass bottle & 20 & 4700 & 300 \\
\hline TOP coco pina & $50 \mathrm{cl}$ & Glass bottle & 20 & 4700 & 300 \\
\hline
\end{tabular}

With the aim of attracting consumers, the three enterprises mentioned above carry out practically the same actions with retailers: giving the latter refrigerators in the company's colors and decorated with that company's products; painting the facades of bars and refreshment stands in the company's colors, highlighting certain products, and providing them with advertising materials (trays, glasses, parasols, chairs, tables, etc.). BRASCO supplied its exclusive distributors with beverage delivery vehicles. Consumers are more appreciative of juice in glass bottles for reasons of better conservation. However, the juice in a plastic bottle is easier to take away, given that it does not require any exchange bottle. Gender-specific flagship products for each company are presented in Table $n^{\circ} 4$ below; and it highlights each company's top-selling products by gender. For BRASCO, gender discrimination is strict.
For RAGEC and BRALICO there are, however, products that can be found in both the Women's column and the Men's column. Noteworthy is the fact that men appreciate the "cola" or "coca" product of each of these companies. 
Table $n^{\circ} 4$ : Demand for Gender-specific flagship products per company

\begin{tabular}{|c|c|c|}
\hline Company & Women & Men \\
\hline BRASCO & Pulp orange, Fanta passion & Coca cola \\
\hline RAGEC & Orangina, Tampico orange, Tampico pomme & Réaktor, American cola, Tampico pomme \\
\hline BRALICO & Top passion, Coca world & Coca world \\
\hline
\end{tabular}

Source: Tsana and Abdelkerim (2018)

\section{a) Organization of the questionnaire}

The questionnaire that served as the data collection medium was administered to ESGAE students (Ecole Supérieure de Gestion et d'Administration des Entreprises - a College of Business Administration), during the 2019-2020 academic year in Brazzaville, Congo.

Among ESGAE students, the study targeted 679 students at the following levels: Bachelor's degree 3 (professional degree), CESAE (Certificate of Higher Studies in Business Administration) and the professional Master's degree. The questionnaire is structured a round the following four axes:

- Axis1: the perception on the advertising logo;

- Axis 2: the attractiveness of soft drinks based on the logo;

- Axis 3: the company notoriety through its logo;
- Axis 4: the place of communication in these enterprises.

The modality "No answer" corresponds to the number of students who did not answer the question. The most frequent case in this study refers to questions that were not completed.

b) Sample presentation

The sample is made up of 297 students whose data is complete upon completion of the questionnaire, with a response rate of $43.74 \%$.

\section{c) Gender structure}

The 297 respondents to the questionnaire are distributed as follows: 166 women (representing (55.89\%) and 131 men (representing 44.11\%) (see Figure 1)

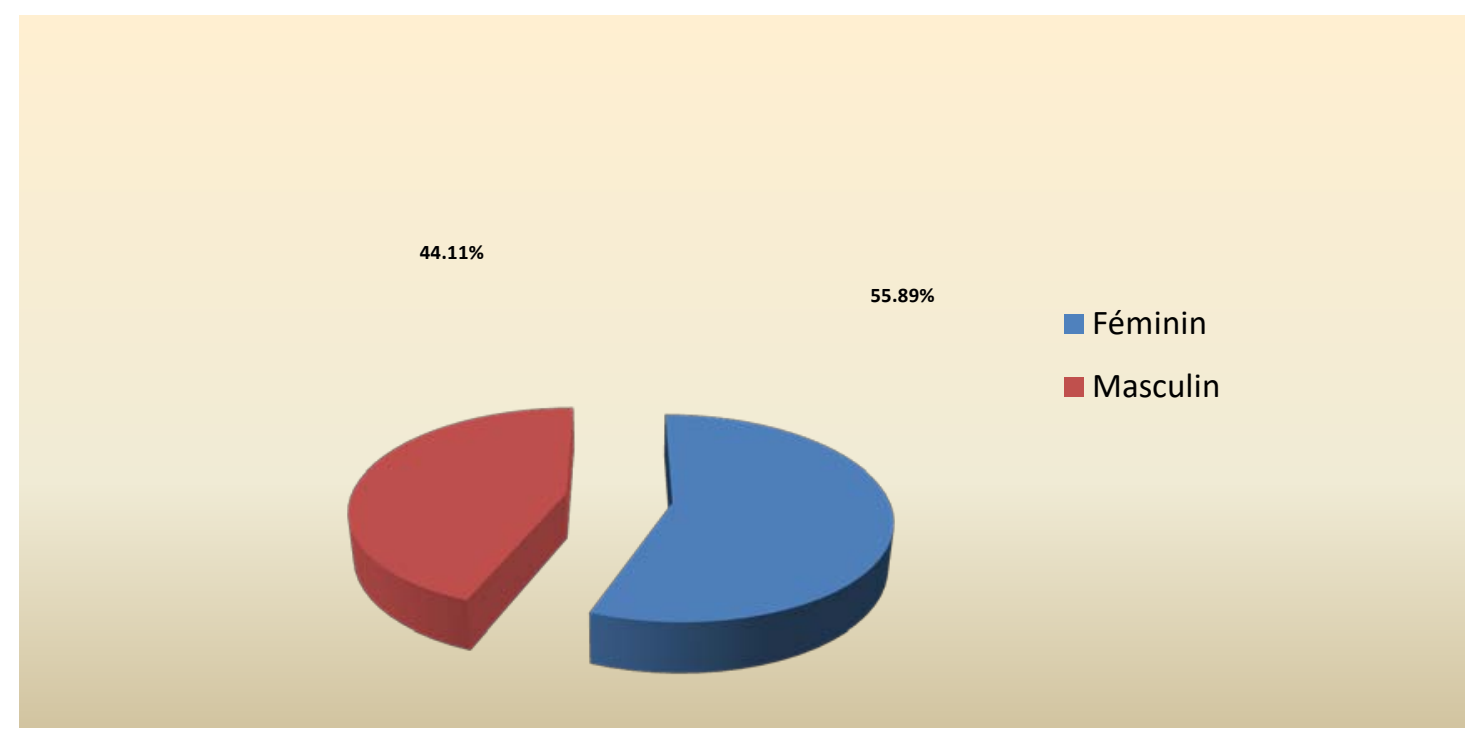

Legend in blue: Female

Legend in brown: Male

Structure by educational level

Figure 1: Workforce representation by gender

The breakdown of respondents by level of education shows that $46.47 \%$ are Master's students, whereas 33.33\% are Bachelor's students, and 20.20\% are CESAE students (see Figure 2). 


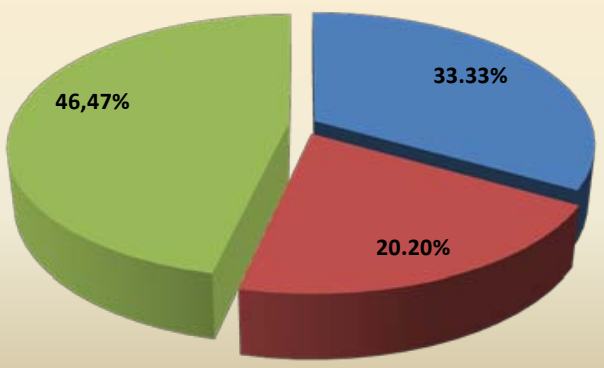

- Licence

- CESAE

Master

Legend in blue: Bachelor degree

Legend in brown: CESAE

Legend in gray: Master degree

Figure 2: Workforce representation by educational level

Age structure

The age of the students involved in the study ranges from 19 to 55 years old, with an average age of about 30 . The population is $61 \%$ under 30 years of age, with a very high concentration at $40 \%$ for the interval

between 20 and 24 years inclusive. This age group is also characterized by a remarkable presence of women (see. figure 3).

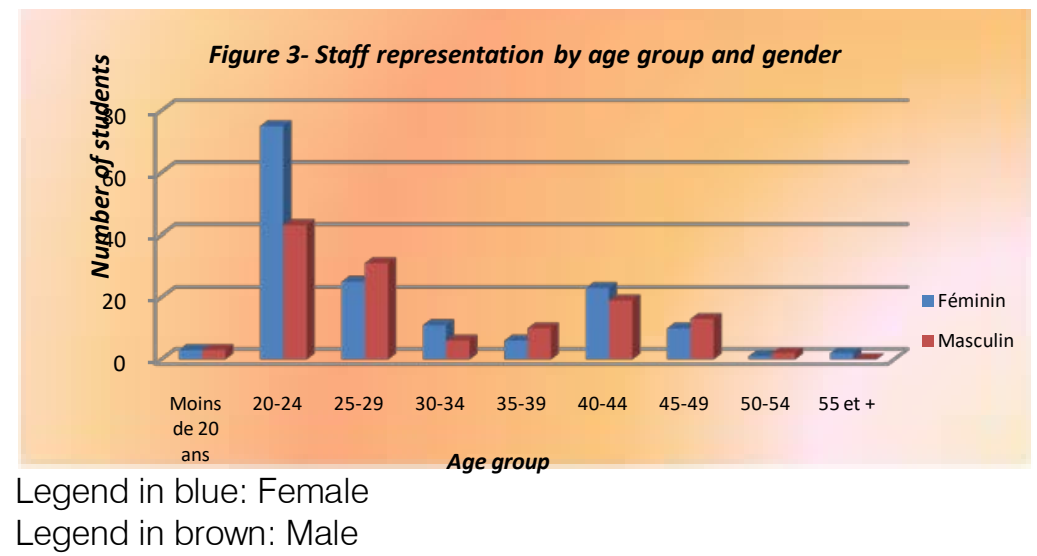

Figure 3: Staff representation by age group and gender

\section{d) Discussion}

The results and discussions are presented according to four headings or axes:

$\mathrm{H} 1.1$ and $\mathrm{H} 1.2$.

Examination of $\mathrm{H} 1.1$

Table $n^{\circ} 5$ : Breakdown of staff by level of education on expectations about the content of a soft drink logo

\begin{tabular}{|c|c|c|c|c|c|}
\hline & No answer & Yes & No & I don't know & Total \\
\hline Licence & 0 & 69 & 23 & 7 & 99 \\
\hline CESAE & 2 & 30 & 25 & 3 & 60 \\
\hline Master & 0 & 44 & 79 & 15 & 138 \\
\hline TOTAL & 2 & 143 & 127 & 25 & 297 \\
\hline
\end{tabular}

Dependency is very significant. Khi2 $=42.72, d d l=6,1-p=>99.99 \%$ e) Perception on the advertising logo

To test students 'perceptions of the logo advertising discourse, we have looked at hypotheses. 
The level of education has a very strong influence on whether the content of a drink's logo always meets the consumer's expectations. On that matter, Maynadier (2014) states that "The logo must refer to the issuing organisation and become a reference sign. The logo is thus a sign of the different elements issued by an organisation, such as a service, a product or an advertisement. Increasingly integrated within brands of which it is a crucial element, the logo is responsible for manifesting elements that structure it".
The educational level of the surveys is highly solicited because, as receivers, they must give meaning to the signs represented by the logos.

\section{Examination of $\mathrm{H} 1.2$}

$52.86 \%$ of respondents believe that the objectives indicated by the logo are precise, compared to the other $30.98 \%$. On the other hand, it was not easy for some respondents (15.15\%) to express a clear opinion on the "precise" nature of the objectives on a logo.

Table $n^{\circ} 6$ : Breakdown of staff by gender on the precision of the objectives indicated by the logo

\begin{tabular}{|c|c|c|c|c|c|}
\hline & No answer & Yes & No & I don't know & Total \\
\hline Male & 2 & 57 & 43 & 29 & 131 \\
\hline Female & 1 & 100 & 49 & 16 & 166 \\
\hline TOTAL & 3 & 157 & 92 & 45 & 297 \\
\hline
\end{tabular}

Dependency is very significant. Khi2 $=12.30, d d l=3,1-p=99.36 \%$.

Maynadier (2014) notes that the logo "must be able to express values and stories corresponding to the brand". However, when it comes to values, Dorez and Zollinger (2000) distinguish - in advertising discourse male values focused on performance and technical sophistication, female values emphasizing ease of use and product accessibility, and shared values that tend to be more in line with female values. Advertisements also emphasize the importance of the level of education as these, in order of importance, should be: clear and easily understandable, informative, persuasive and motivational (Chevalier, 1999)

Table $n^{\circ} 7$ : Breakdown of staff by level of education on the precision of the objectives indicated by the logo

\begin{tabular}{|c|c|c|c|c|c|}
\hline & No answer & Yes & No & I don't know & Total \\
\hline Bachelor & 2 & 67 & 20 & 10 & 99 \\
\hline CESAE & 0 & 35 & 17 & 8 & 60 \\
\hline Master & 1 & 55 & 55 & 27 & 138 \\
\hline TOTAL & 3 & 157 & 92 & 45 & 297 \\
\hline
\end{tabular}

Dependency is very significant. Khi2 $=21.51, d d l=6,1-p=99.85 \%$.

To check whether the objectives indicated by the logo are precise, gender and level of education have had a very strong influence on the results obtained.
Attractiveness of soft drinks from the logo

To understand logo-based soft drink appeal, we have examined assumptions or hypotheses $\mathrm{H} 2.1$ and $\mathrm{H} 2.2$

\section{Examinationof $\mathrm{H} 2.1$}

Table $n^{\circ}$ 8: Breakdown of staff by gender on the existence of a link between the logo and the color of the soft drink

\begin{tabular}{|c|c|c|c|c|c|}
\hline & No answer & Yes & No & I don't know & Total \\
\hline Male & 3 & 61 & 59 & 8 & 131 \\
\hline Female & 6 & 101 & 49 & 10 & 166 \\
\hline TOTAL & 9 & 162 & 108 & 18 & 297 \\
\hline
\end{tabular}

Dependency is significant. Khi2 $=8.01, d d l=3,1-p=95.42 \%$

According to Jonveaux (2015), "the first visual element that tries to convey a gender-based message is color". This means that color induces gender differentiation. Irrespective of age, Congolese people attach great importance to colors in general, and particularly in clothing. The phenomenon of "SAPE" (which literally stands for "society of well-dressed people who like having good time") that consists of harmonizing colors in clothing, is popularized by both men and women. And flashy colors are on display in the parade of "sapeurs" (well-dressed people of the "SAPE" movement) in public squares. Colors participate in the cosmetic function of advertising. Therefore, the link between logo and color can be culturally understood from the gender approach. 
In the link between the logo and the color of the soft drink, gender has a strong influence.

\section{Examination of $\mathrm{H} 2.2$.}

$70.00 \%$ of respondents think that "the packaging of a soft drink makes them want to buy it".
This phenomenon is observed among men (75.57\%) and women (65.66\%).

Tableau $n^{\circ}$ 9: Breakdown of staff by gender on the purchase of a soft drink from the package

\begin{tabular}{|c|c|c|c|c|c|}
\hline & No answer & Yes & No & I don't know & Total \\
\hline Male & 3 & 99 & 26 & 3 & 131 \\
\hline Female & 0 & 109 & 52 & 5 & 166 \\
\hline TOTAL & 3 & 208 & 78 & 8 & 297 \\
\hline \multicolumn{7}{|c|}{ Dependency is significant. Khi2 $=8.64, d d l=3,1-p=96.56 \%$}
\end{tabular}

The packaging used for soft drinks is plastic, glass bottles and cans. However, there is more plastic packaging than bottles, and very little in cans. Indeed, it is difficult to have empties for purchases of glass bottles; That is the reason why plastic has become an important part of the primary, secondary and tertiary packaging of soft drinks. We have observed a significant change in the content of soft drink packaging. We have 60-centilitreand 30-centilitre primary packaging in bottles. This confirms one of the requirements for the manufacture of the packaging. "the packaging shall be designed and manufactured so as to limit both its volume and its mass to the minimum necessary to ensure the required level of safety and acceptability" (Pinet, 2004).

Soft drinks sold in plastic packaging are cheaper than the others on the one hand, and they are easily transportable on the other hand. In markets, where women are the most numerous, beverages in plastic packaging are the most widely used, given that such packaging can be either disposed of more easily, or recovered for other purposes (sale of home-made yoghurts, ginger juice, bissap juice). We note a change in habits or custom in Congo, on the ground that plastic secondary packaging for soft drinks is now accepted at traditional or customary wedding ceremonies.

Jonveaux (op.cit.) has noted that gender differentiation is particularly sensitive in the case of products which remain identical in their active ingredient, but whose only external aspects, such as odor or especially packaging, vary". In other words, packaging induces gender differentiation.

To test or check whether the packaging of a soft drink is an incentive to buy that soft drink, gender has a significant influence on these results.

\section{Company notoriety through the logo}

To check company's notoriety through the logo, we have examined Hypothesis $\mathrm{H} 3$.

\section{Examination of $\mathrm{H} 3$}

$62.27 \%$ of respondents believe that "there is a link between the logo and the company's brand image". This phenomenon is observed among men (63.36) and women (57.83).

Table $n^{\circ} 10$ : Breakdown of staff per age on the existence of a link between the logo and the company's brand image

\begin{tabular}{|c|c|c|c|c|}
\hline & Yes & No & I don't know & Total \\
\hline No answer & 10 & 1 & 3 & 14 \\
\hline Lessthan 20.00 & 4 & 2 & 0 & 6 \\
\hline From 20.00 to 24.00 & 63 & 23 & 13 & 99 \\
\hline From 24.00 to 30.00 & 50 & 12 & 11 & 73 \\
\hline 30.00 and more & 52 & 41 & 8 & 101 \\
\hline TOTAL & 179 & 79 & 35 & 293 \\
\hline
\end{tabular}

Dependency is significant. Khi2 $=19.01, d d l=8.1-p=98.52 \%$

Noteworthy is the difference between the chronological or actual age of the consumer and the subjective or perceived age at which one tends to perceive oneself 10 to 15 years younger than one's actual age (Guiot, 1999). In our sample, ESGAE students are public servants who are experiencing a second youth by returning to school, and there is no doubt that they are within the dynamics of subjective age.

As pointed out by Sohier (2004), "Building the company's brand image is a learning process based on the consumer's experience with the brand." As experience is built up over the years, the brand image therefore correlates with the consumer's age. 
Place of communication in companies

To understand the place of communication in companies, we have examined $\mathrm{H} 4$

\section{Examination of $\mathrm{H} 4$}

Respondents are relatively divided on this variable. They estimate at $44.44 \%$ that "the message of the logo is always explicit", as opposed to $41.75 \%$. On the other hand, the need to verify the invariable or permanent character could explain the difficulty experienced by those who preferred to answer "I don't know" at 9.76\%.

Table $n^{\circ} 11$ : Breakdown of the workforce by gender on the permanent explicit character of the message of the logo

\begin{tabular}{|c|c|c|c|c|c|}
\hline & Noanswer & Yes & No & I don't know & Total \\
\hline Male & 4 & 47 & 71 & 9 & 131 \\
\hline Female & 8 & 85 & 53 & 20 & 166 \\
\hline TOTAL & 12 & 132 & 124 & 29 & 297 \\
\hline
\end{tabular}

Dependency is very significant. Khi2 $=15.14, d d l=3,1-p=99.83 \%$.

Table $n^{\circ} 12$ : Breakdown of staff by level of education on the "always explicit" message

\begin{tabular}{|c|c|c|c|c|c|}
\hline & Noanswer & Yes & No & I don't know & Total \\
\hline Bachelor & 6 & 53 & 28 & 12 & 99 \\
\hline CESAE & 3 & 31 & 23 & 3 & 60 \\
\hline Master & 3 & 48 & 73 & 14 & 138 \\
\hline TOTAL & 12 & 132 & 124 & 29 & 297 \\
\hline
\end{tabular}

Dependency is very significant. Khi2 $=18.33, d d l=6,1-p=99.45 \%$

The logo visually communicates a message to consumers about a product, service or organization. In such a context where sight is one of the consumer's most solicited senses, "color has thus become an element of differentiation for products whose technical characteristics are subject to the burden of standardization and the consequent trivialization" (Guichard, Lehu and Vanheems, 1998). This is particularly the case with soft beverages and their plastic packaging. We have seen with the validated hypothesis $\mathrm{H} 2.1$ that there is a link between the logo and the color according to the gender. We can therefore conclude that the message of the logo, being strongly linked to color-which is itself an element of differentiation -is explicit. Celhay (2014) points out that "companies may use the visual characteristics of an advertisement, packaging or logo to convey messages, explicit or implicit, to their consumers".

Theoretical model of the Swiss linguist Ferdinand de Saussure postulates that signs can be interpreted in two ways: the signifier and the signified. The signifier being the physical manifestation of the sign, we place ourselves at the level of expression. The signified being the meaning that is given to the signifier, we are at the level of content. As indicated by Celhay (op. cit.)," if we apply these concepts to the case of logos, it appears that the verbal content, as well as each of their visual characteristics (colors, illustrations, typography, shapes, textures, etc) constitute as many signifiers that the company can use for communication purposes, for example on the positioning of its brand (which then constitutes the signified)". The level of education of the consumer is very important for a good understanding of both the signifier and the signified. When the message is not explicit in this respect, the level of education may be a factor that may lead the consumer to resist the logo's message: "the more educated and informed the consumer is, the more likely he is to resist influencing techniques owing to the greater richness of his representations" (Cottet, Ferrandi and Lichté, 2012).

To check whether the message of the logo is always explicit, gender and level of education have had a very strong influence on the results obtained.

\section{Conclusion}

Despite the inherent constraints in building our sample, we have obtained empirical results on an operational aspect of marketing, namely commercial communication. The multiplicity of messages conveyed by issuers raises the issue of the credibility of those issuers, and that of the true or real source of the message. Indeed, in this increasingly liquid communication, ethical problems are acute, because commercial communication has become subtle and difficult to identify as such: it hides its name (TissierDesbordes, 2013). The advertising logo as a marketing discourse does not escape this debate. By taking into account a population of students, we have placed ourselves in a context where the consumer has become not only a researcher, but also an actor of knowledge. The validation of our corpus of hypotheses has highlighted gender, age and level of education as 
variables that made it possible to apprehend the perception of the discourse of advertising logos.

\section{References Références Referencias}

1. Bergadaà, M., (2000). La mutation de la recherche en marketing: L'analyse du "genre " comme exemple. Décisions Marketing, 20, 23-34.

2. Celhay, F., (2014). Impact du design du logo et du nom de la marque: un effet de double ancrage. Communication au $30^{\text {ème }}$ Congrès International de l'Association Française du Marketing, Montpellier, Mai, 20p.

3. Chevalier, C., (1999). La perception des publicités par les seniors. Décisions Marketing, 18, 41-49.

4. Cottet, P., Ferrandi, JM \& Lichtlé, M.C., (2012) Les consommateurs résistants à la publicité. Leurs principales actions et motivations. Décisions Marketing, 68, 25-36.

5. Cova, B. \& Saucet, M., (2014) Le street marketing, forcément transgressif? Décisions Marketing, 73, 27-43.

6. Filser, M., (2015). Vers une consommation plus affective. Revue Française de Gestion, 253, 173187.

7. Flambard-Ruaud, S., (1987) Les évolutions du concept de marketing. Décisions Marketing, 11, 7-20.

8. Gavard-Perret, M.-L., (2000). D'un marketing aux valeurs masculines à un marketing aux valeurs féminines. Décisions Marketing, 20, 11-20.

9. Guichard, N., Lehu, J.M. \& Vanheems, R., (1998). Marketing du cinquième sens: l'aromachologie au service de la stratégie? Décisions Marketing, 14, 7-17.

10. Granier, C. \& Guilbaut, B., (1982): «Gestion commerciale et mercatique » Tome 2. Clet, Editions Banque Paris.

11. Guiot, D., (1999). Age subjectif et segmentation des seniors. Décisions Marketing, 18, 15-23.

12. Ibara, M., (2013). Eco-Publicité et dynamique de la structure du marché des produits de consommation de masse au Congo : l'agent écologique intelligent. Thèse de Doctorat en Sciences de Gestion, Université Libre Internationale de Bruxelles, Belgique, 2013.
13. Jonveaux, I., (2015). Un construit économique? Produits de consommation et différenciation de genre. Le cas des gels douche. Sociologie du travail, 57(2), 230-249.

14. Kapferer, J. N., (2003). Réinventer la marque. Revue Française de Gestion, 145(29), 119- 130.

15. Lelarge, G., (1989). Organisation et gestion de l'entreprise. Clet, Editions Banque Paris.

16. Maynadier, B., (2014). De quoi le logo d'une ville est-il le signe ? Décisions Marketing, 74, 115-127.

17. Mazière, F., (2005). L'Analyse du discours, Paris, PUF, 2005, p. 110.

18. Mérigot, P. \& Nabec, L., (2016). Les effets d'alerte et de promotion des logos nutritionnels sur la faceavant des produits agroalimentaires. Décisions Marketing, 83, 29-47.

19. Philippe, D. \& Durand, R., (2009). Communication environnementale et réputation de l'organisation. Revue Française de Gestion, 194, 45-63.

20. Pinet, B., (2004). Développement durable et marketing de l'emballage. Revue Française de Marketing, 200, 27-38.

21. Remaud, H. \& Sirieix, L., (2012). Les vins écolabellisés face aux vins conventionnels en France et en Australie. Quelle perception des consommateurs et quelles implications marketing? Décisions Marketing, 67, 23-35.

22. Rouveyrol L., (2005). Vers une logométrie intégrative des corpus politiques médiatisés. L'exemple de la subjectivité dans les débats-panel britanniques, Corpus, $n^{\circ}$ 4, 2005.

23. Sohier, G., (2004).L'influence de la couleur et de la forme du packaging du produit sur la perception de la personnalité de la marque. Thèse de doctorat de l'Université de Caen, France, 353p.

24. Tissier-Desbordes, E., (2013). Communication liquide et enjeux éthiques. In Eclairages sur le marketing de demain: prises de décisions, efficacité et légitimité. Décisions Marketing, 72, 17-42.

25. Tsana, L. E \& Abdelkerim, M., (2018).La diversification stratégique des produits de la société RAGEC. Mémoire de master en management stratégique et prospective stratégique. ESGAE, Brazzaville, $46 \mathrm{p}$.

\section{Annex: Questionnaire}

After the research question, which is:

How can consumers better perceive the discourse proposed to them by the product's advertising logos?

Further to this core question, the following questions arise:

Q1- Does the content of a drink's logo always meet your expectations?

- Yes;

- No;

- I don't know. 
Q2- Are the objectives indicated by the logo precise?

- Yes;

- No;

- I don't know.

Q3- Is there any link between the logo and the product?

- Yes:

- No;

- I don't know.

Q4- Do you see the importance of the logo throughout the product?

- Yes;

- No;

- I don't know.

Q5- Are there any other advertising means that the company uses besides the logo?

- Yes ;

- No;

- I don't know.

Q6- Does the logo always indicate the quality of the product?

- Yes;

- No ;

- I don't know.

Q7- Does the logo always lead to the purchase of the product?

- Yes:

- No ;

- I don 't know.

Q8- Is there any link between the logo and the company's brand image?

- Yes;

- No;

- I don't know.

Q9- Is there any link between the logo the product price?

- Yes;

- No ;

- I don't know.

Q10- lis the message of the logo always explicit?

- Yes;

- No;

- I don't know.

Q11- Is there any link between the logo and the color of the product?

- Yes ;

- No;

- I don't know.

Q12- through the advertising logo, could you recommend a company's product?

- Yes;

- No ;

- I don't know.

Q13- do soft drink companies improve compliance through their logo?

- Yes;

- No;

- I don't know. 
Q14- have you ever been in a situation where you buy a product under social pressure?

- Yes:

- No ;

- I don't know.

Q15- faced with two products that look alike, is there any determining factor that leads the consumer to a givenlogo?

- Yes:

- No ;

- I don't know.

Q16-Are you familiar with these products owing to various advertisements?

- Yes;

- No;

- I don't know.

30 Q17- does the packaging of a product make you want to buythat product?

- Yes;

- No;

- I don't know. 